\title{
Chemical constituents of apolar fractions from fruit latex of twelve Clusia species (Clusiaceae)
}

\author{
CLAUDIO A.G. DA CAMARA ${ }^{1}$, ANITA J. MARSAIOLI ${ }^{2}$ and VOLKER BITTRICH ${ }^{3}$ \\ ${ }^{1}$ Departamento de Química, Universidade Federal Rural de Pernambuco, Av. \\ Dom Manoel de Medeiros, s/n, 52171-900 Recife, PE, Brazil \\ ${ }^{2}$ Instituto de Química, Universidade Estadual de Campinas, Cidade Universitária \\ Zeferino Vaz, Caixa Postal 6154, 13083-970 Campinas, SP, Brazil \\ ${ }^{3}$ Instituto de Biologia, Universidade Estadual de Campinas, \\ Cidade Universitária Zeferino Vaz, 13083-862 Campinas, SP, Brazil
}

Manuscript received on April 4, 2017; accepted for publication on July 4, 2017

\begin{abstract}
The apolar fractions components of fruit latex of twelve species of Clusia belonging to four different taxonomic sections were examined by GC-MS. The latex of Clusia is characterised by large amounts of sesquiterpene hydrocarbons as major constituents like germacrene D: C. paralicola (44.28 \%), C. criuva subsp. criuva (29.03\%); $\beta$-caryophyllene: C. fluminensis (35.61\%), C. lanceolata (36.39\%), C. hilariana (58.10\%); $\alpha$-trans-bergamontene: $C$. spirictus-sanctensis (36.30\%); $\alpha$-bulnesene: $C$. weddelliana (25.61 $\%$ ); bicyclogermacrene: $C$. panapanari (25.93\%) and trans- $\beta$-farnesene: $C$. nemorosa (24.63\%), while C. grandiflora is composed of $42.16 \%$ monoterpene hydrocarbons. Verbenone (31.91\%) was the major component. In contrast, C. rosea, C. grandiflora, C. lanceolata and C. criuva subsp. parviflora are rich in 3-methylcyclohexanone (19.56\%), hexadecanol (22.72\%), p-anisaldehyde (23.39\%) and octadecanol (26.81\%), respectively. This study suggests considerable chemical variation among the non-polar fractions of fruit latex of the twelve Clusia species.
\end{abstract}

Key words: Clusia spp., latex, apolar fraction, $\beta$-caryophyllene, verbenone.

\section{INTRODUCTION}

Many plants can store a great diversity of liquids and fluids, including latex, resins, mucilage and gums in specialised cells, channels and/or intercellular cavities. The latex can be defined as a water-based suspension or emulsion of various types of small

Correspondence to: Claudio Augusto Gomes da Camara

E-mail: claudio_agc@hotmail.com

* Contribution to the centenary of the Brazilian Academy of Sciences. particles. Latex is accumulated either in living cells and/or specialised structures called laticifers (Lewinsohn 1991) or in intercellular secretory canals or ducts lined by epithelial cells secreting substances into the canal. The latter is the case in the close families Clusiaceae, Calophyllaceae and Hypericaceae (Vismia). The aqueous suspension is generally constituted by an infinity of compounds belonging to a variety of classes, including inorganic constituents. Among the secondary compounds 
present in these suspensions, mainly terpenoids, fatty acids, aromatic compounds, hydrocarbons and alkaloids are found (Konno 2011, Hua et al. 2015).

The roles of laticifers or secretory canals and latex in plants are up to now not completely clear, but it is generally assumed that they serve to store nutrients or that the latex has a distribution function for these nutrients for the different plant parts (Agrawal and Konno 2009). Other functions described for latex production units are regulation of water storage and oxygen transport in plants, and especially the protection of the plant against natural enemies, more precisely, microorganisms and herbivores (Hua et al. 2017). Comparison between closely related plant groups led to the hypothesis that the presence of latex is directly related to plant survival and species richness of clades (Farrell et al. 1991). As plants with latex are observed with a higher frequency in Eudicotyledoneae, one estimates that about 40 families and more than 20,000 species are latex or resin producers (Konno 2011). Of these species, among the most important are the ones of the family Clusiaceae that can store in the latex and in the floral resin different classes of secondary compounds.

The neotropical genus Clusia L. (Clusiaceae) has attracted the interest of botanists for its resin producing flowers, which are collected especially by Euglossinia and Trigonini bees. Chemical research revealed that these resins are mainly composed of polyisoprenylated benzophenones (Porto et al. 2000, Anholeti et al. 2015) and have shown HIV-inhibitory activity (Wu et al. 2014).

Like all members of the family Clusiaceae, Clusia plants have latex in nearly all their tissues. Quantities and colour of the latex vary among the species but also between different plant organs of one plant. The latex, extracted mainly from fruits of the Clusia species has been used in popular medicine by ingestion for rheumatic treatment (Sanz-Biset et al. 2009) and infant oral candidiasis (Barbosa and
Pinto 2003). Up to the present moment, only one study referring to the chemical composition of latex from Clusia has been realized, which was restricted to $C$. grandiflora species where the antimicrobial activity of two polyisoprenylated benzophenones obtained from the latex of stems was reported (Lokvam et al. 2000).

The present work has the objective to investigate the chemical composition of the apolar fraction of latex from fruits of twelve Clusia species pertinent to four sections (Chlamydoclusia, Criuva, Phloianthera and Cordylandra).

\section{MATERIALS AND METHODS}

\section{COLLECTION OF PLANT MATERIAL}

The latex were obtained from fruits of Clusia species cultivated on the "Fazenda Santa Elisa", Agronomic Institute of Campinas (IAC), Campinas - SP, Brazil. Maria do Carmo Estanislau do Amaral and Volker Bittrich have deposited voucher specimens in the Herbarium of the State University of Campinas (UEC). The latter was responsible for the identifications. The species studied and herbarium numbers are listed in Table I.

\section{EXTRACTION OF LATEX}

The exuded latex of plants was obtained from freshly cut fruits and collected onto methanol. Filtration and solvent evaporation produced methanolic extract. The triplicated yields were average and calculated based on fresh weight of the fruit. The fruits from different Clusia species were collected randomly.

\section{ISOLATION OF APOLAR COMPONENT}

Methanolic extract was dissolved in dichloromethane $(30 \mathrm{~mL})$ and filtrated on $2.0 \mathrm{~g}$ of silica gel 60 on glass column $(\varnothing=1 \mathrm{~cm})$. The collected dichloromethane fraction was dried over anhydrous sodium sulphate and reduced to ca. 0.5 $\mathrm{mL}$ at room temperature under reduced pressure on 
a rotatory evaporator and stored in sealed vials at low temperature before analysis. Three replicated analyses were used for some species (C. paralicola, C. fluminensis, C. lanceolata, C. criuva subsp. parviflora, C. grandiflora, and C. rosea).

GAS CHROMATOGRAPHY FID (GC-FID) AND GAS CHROMATOGRAPHY-MASS SPECTROMETRY (GCMS) ANALYSIS

Analyses were carried out using a HP-5990/5970 system equipped with a flame ionization detector (FID) and J\&W Scientific non-polar DB-5 fused silica capillary column $(30 \mathrm{~m} \times 0.25 \mathrm{~mm} \times 0.25$ $\mu \mathrm{m})$; column temperatures were programmed from 60 to $240{ }^{\circ} \mathrm{C}$ at $3{ }^{\circ} \mathrm{C} \min ^{-1}$ for integrating purposes.

\section{GC-FID ANALYSIS}

Injector and detector temperatures were 220 and $285^{\circ} \mathrm{C}$ respectively. Hydrogen was used as carrier gas at a flow rate $1.16 \mathrm{ml} \mathrm{min}^{-1}$ in the split mode (1:30), with an injection volume, $1.0 \mu \mathrm{L}$ solution of about $10 \mathrm{mg}$ of latex in $1 \mathrm{~mL}$ of dichloromethane. The amount of each compound was calculated from GC peak areas in the order of DB-5 column elution and expressed as a relative percentage of the total area of the chromatograms. The retention indices were obtained by co-injecting the oil sample with a $\mathrm{C}_{11}-\mathrm{C}_{24}$ linear hydrocarbon mixture (retention index from 900 to 1099 range was obtained by extrapolation).

\section{GC-MS ANALYSIS}

The carrier gas was helium and the temperature program was the same as that for GC experiments. The mass spectra were taken at $70 \mathrm{eV}$ with a scanning speed of $0.84 \mathrm{scan} \mathrm{s}^{-1}$ from $\mathrm{m} / \mathrm{z} 40$ to 550 .

The latex were analysed by GC and GCMS, and identification was made on the basis of standard compound co-injection and comparison of retention indices (Van den Dool and Kratz 1963) as well as by computerised matching of the acquired mass spectra with those stored in wiley / NBS mass spectral library of the GC-MS data system and other published mass spectra (Adams 2007).

\section{RESULTS AND DISCUSSION}

The latex isolated from the fruits of different Clusia species showed colours from white to yellowish green with characteristic citric odours. The yields (calculated based on fresh fruits weight) of fruits latex of Clusia species are shown in Table I as well as the colour and herbarium number.

This investigation allowed the identification of more than 70 components in the dichloromethane fractions of the late latexes from different Clusia species. In the mean 15 compounds were identified in each species, which are represented in more than $99 \%$ of the fruits latex. In general, even species with the same taxonomic section, showed different composition of the dichloromethane fraction of the latex. With the objective of getting a better visualization of the molecules comprising the apolar latex constituents of the fruits from the different studied species, the identified compounds were allocated in three different compound groups in accordance with the criteria established by Knudsen et al. (1993), which are fatty acid derivatives, isoprenoids and benzenoids (Table II).

Curiously, the five benzenoid compounds identified (benzaldehyde, acetophenone, methyl benzoate, ethyl benzoate and $p$-anisaldehyde), were never found simultaneously in the investigated species. Nevertheless, comparison of the latex composition of these Clusia species shows that, although not being the compound class with the major quantity, benzenoid compounds are characterised (quantity $>0.1 \%$ ) in practically all species, with exception of $C$. panapanari and $C$. spirictu-sanctensis of the section Cordylandra (Table II). The benzenoid compounds present at more than $1 \%$ concentration were acetophenone, section Cordylandra (C. weddelliana, $3.83 \%$ ), section Chlamydoclusia (C. rosea, $10.49 \%$ ), section 
TABLE I

Herbarium number, colour and percentage of fruits latex from Clusia species collected in the Fazenda Santa Elisa of the Agronomic Institute of Campinas - SP, Brazil.

\begin{tabular}{ccccc}
\hline Taxonomic sections & \multicolumn{1}{c}{ Clusia species } & $\begin{array}{c}\text { \% Fruit } \\
\text { latex }\end{array}$ & Colour & $\begin{array}{c}\text { Herbarium } \\
\text { number }\end{array}$ \\
\hline \multirow{3}{*}{ Chlamydoclusia } & C. nemorosa G. Mey. & 0.87 & yellowish green & $\# 95 / 150$ \\
& C. rosea Jacq. & 1.14 & yellowish green & $\# 95 / 154$ \\
Criuva & C. grandiflora Splitg. & 0.12 & white & $\# 95 / 153$ \\
& C. criuva Cambess & 3.97 & yellowish green & $\# 97 / 247$ \\
Phloyanthera & C. parviflora Engl. Nom. Illeg & 3.03 & yellowish green & $\# 97 / 7$ \\
& C. hilariana Schltdl. & 0.66 & white & $\# 97 / 248$ \\
& C. lanceolata Cambess. & 0.56 & yellowish green & $\# 96 / 27$ \\
Cordylandra & C. paralicola G. Mariz & 1.29 & yellowish green & $\# 97 / 5$ \\
& C. weddelliana Planch \& Triana & 0.46 & yellowish green & $\# 2001 / 57$ \\
& C. fluminensis Planch \& Triana & 1.06 & white & $\# 2001 / 54$ \\
& C. panapanari (Aubl.) Choisy & 0.67 & yellowish green & $\# 95 / 156$ \\
& C. spiritu-sanctensis G.Mariz & 0.60 & white & $\# 95 / 185 \mathrm{a}$ \\
\hline
\end{tabular}

Criuva (C. criuva subsp. parviflora, $3.11 \%$ and C. criuva subsp. criuva, $2.73 \%$ ); ethyl benzoate, only present in section Criuva (C. criuva subsp. parviflora, $4.53 \%$ and C. criuva subsp. criuva, 2.34) and $p$-anisaldehyde, in Chlamydoclusia section (C. grandiflora, $1.21 \%$ ), Section Criuva (C. criuva subsp. criuva, $1.11 \%$ ) and section Phloianthera (C. lanceolata, 23.39 \%). Aromatic esters, aromatic aldehydes, aromatic ketone and fatty acid derivatives have been reported to be part of floral scents for Clusia species. However, with the exception of acetophenone, ethyl benzoate, methyl benzoate, $p$-anisaldehyde and benzaldehyde, found in apolar fractions of fruits latex were also identified in the floral essential oil from the same Clusia species here investigated (Nogueira et al. 2001).

By the organisation of the latex constituents in the above-mentioned three groups, independently from taxonomic section, the predominance of compounds from the isoprenoid class became evident. Outstanding are the species of section Cordylandra, where isoprenoid concentration of $91.73-99.19 \%$ were found. In the sections Chlamydoclusia and Phloianthera, only the species C. nemorosa (99.43\%) and C. hilariana (96.92 $\%$ ) show isoprenoid percentages higher than 90 $\%$. The other species show the respective value in the range of $47.50-82.53 \%$. With exception of $C$. grandiflora, which is comprised by $42.16 \%$ monoterpene hydrocarbons with verbenone (31.91 $\%)$ as major component, $C$. rosea and C. criuva subsp. parviflora with 3-methylcyclohexanone $(19.56 \%)$ and octadecanol $(26.81 \%)$ as major constituents, all the other species are characterised by the presence of sesquiterpenes as major components. For example, in $C$. paralicola (44.28\%) and C. criuva subsp. criuva (29.03 $\%$ ), the germacrene D is more abundant. Other sesquiterpenes that were present in high amounts were $\beta$-caryophyllene in $C$. fluminensis $(35.61 \%)$, C lanceolata (36.39\%) and C. hilariana (58.1\%); $\alpha$-trans-bergamontene in C. spirictus-sanctensis (36.30\%); $\alpha$-bulnesene in C. weddelliana (25.61 $\%)$; bicyclogermancrene in $C$. panapanari $(25.93$ $\%)$ and trans- $\beta$-farnesene in $C$. nemorosa (24.63 $\%$ ) (Table II). 


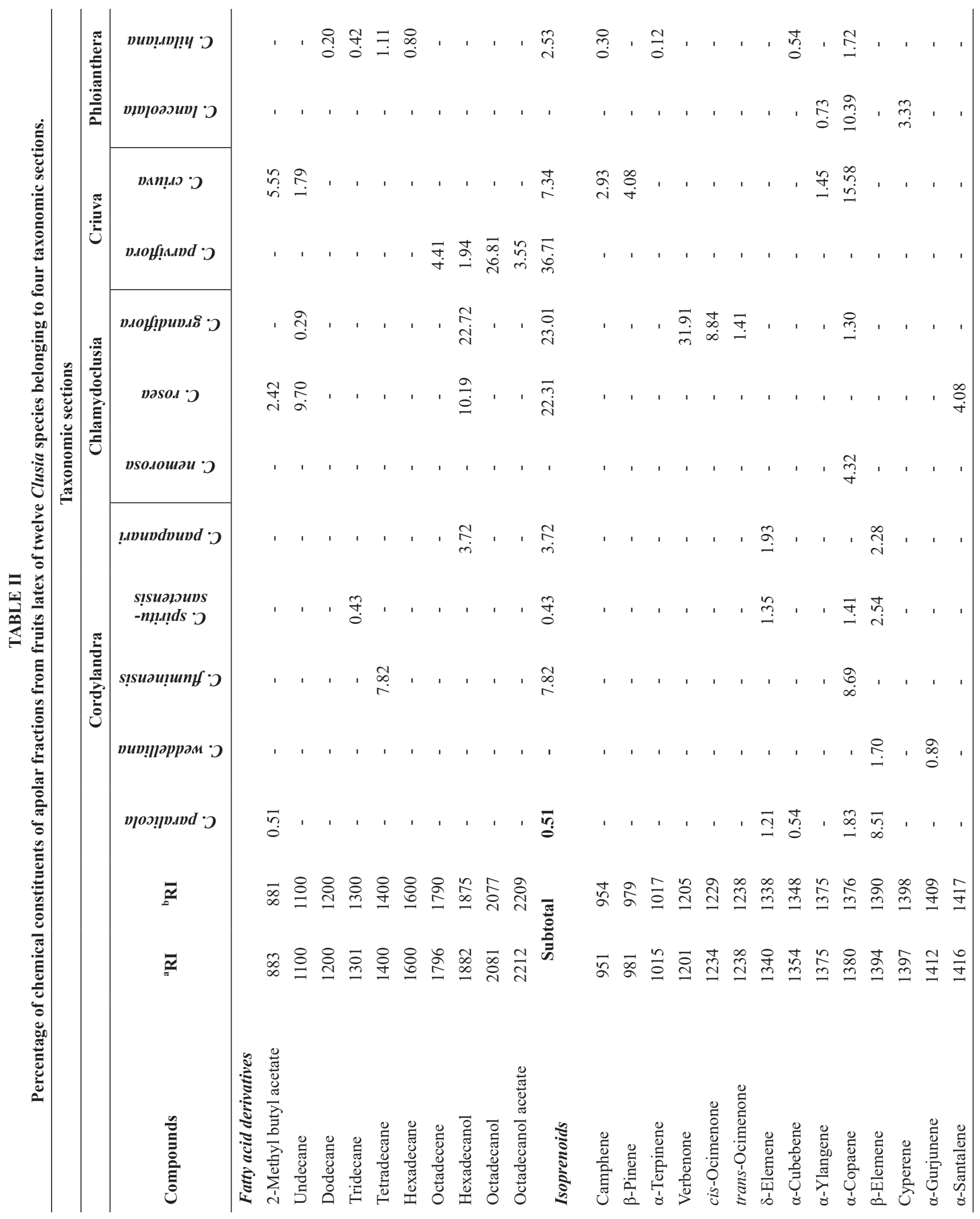




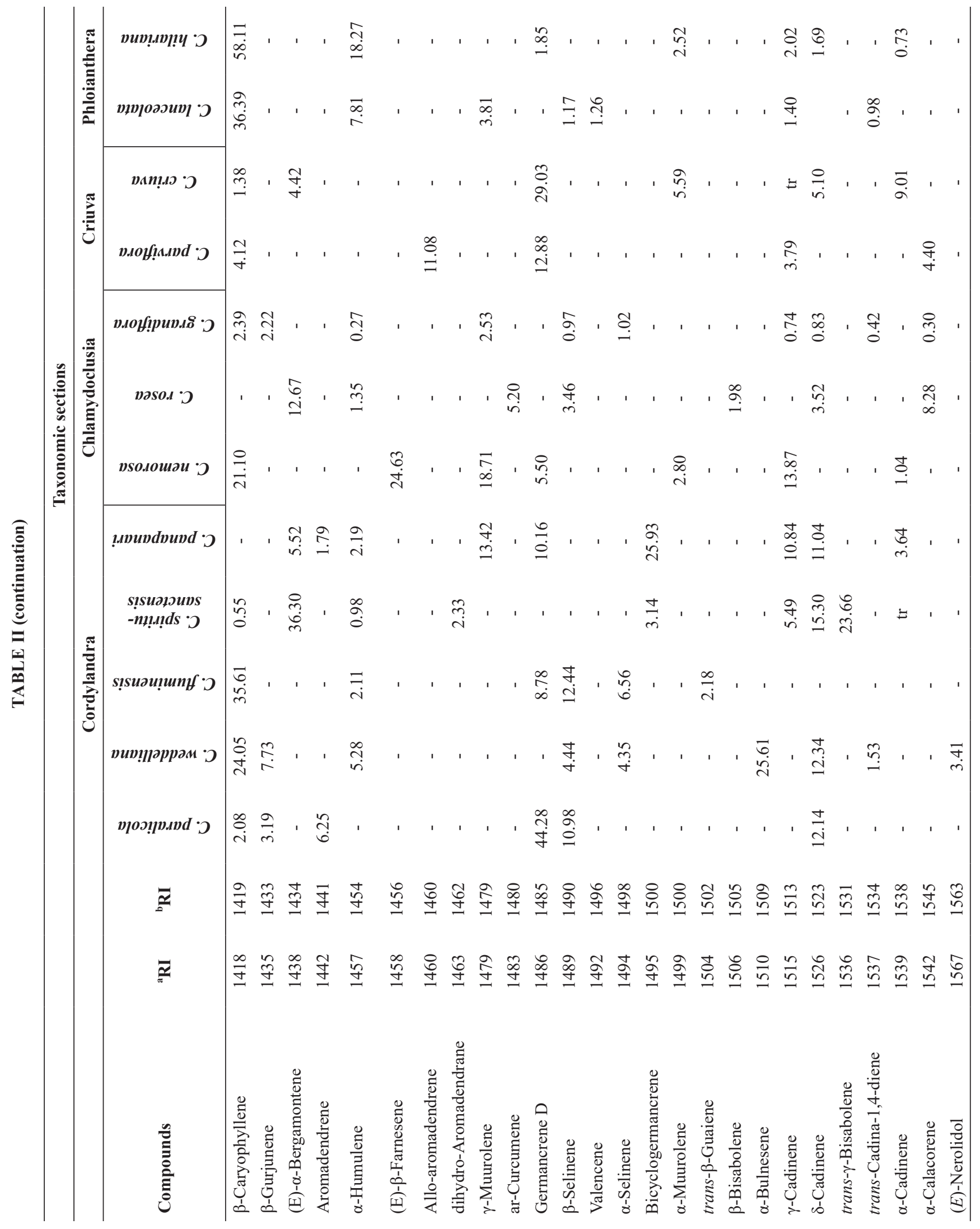




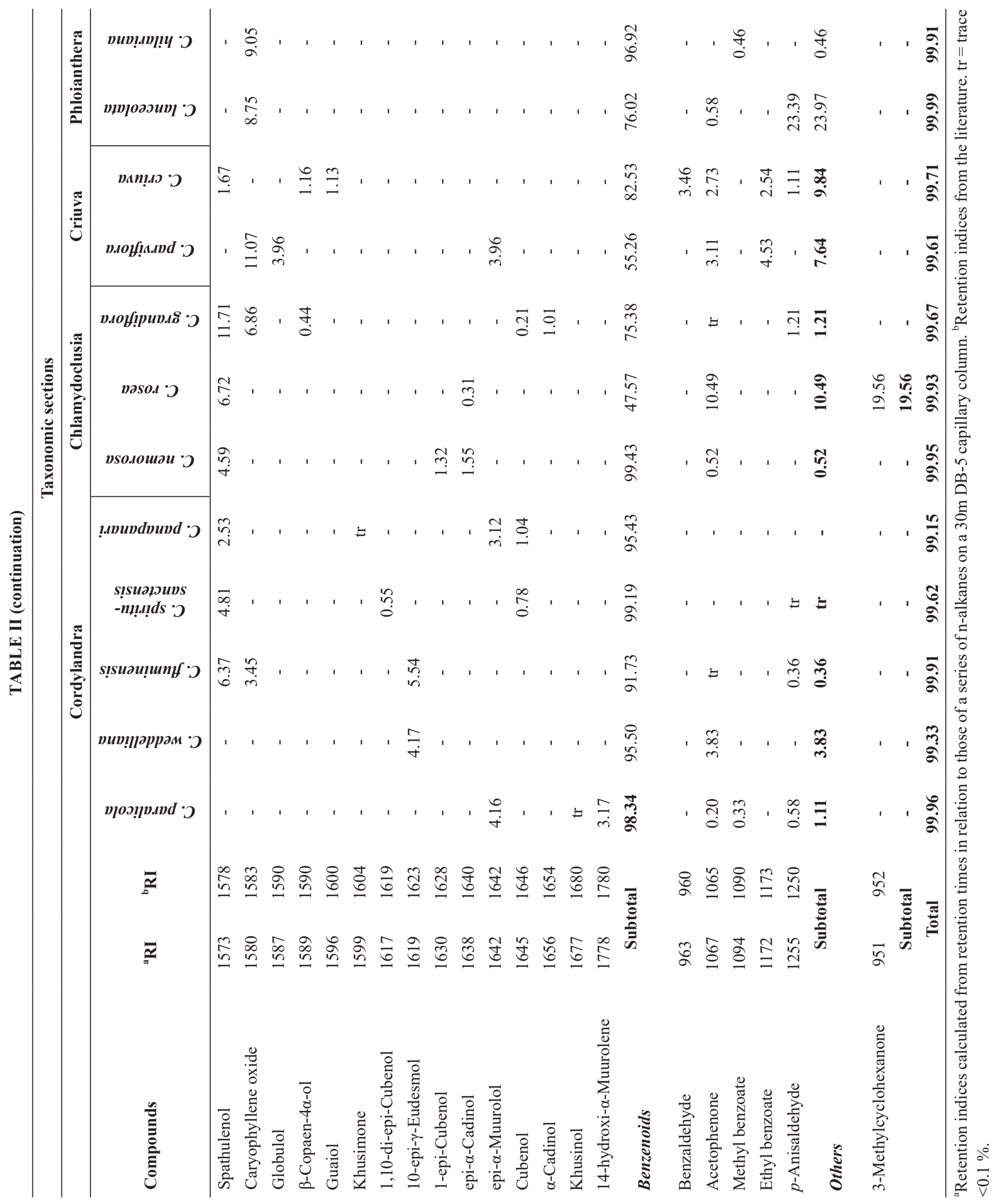


The main constituents of latex present in the different Clusia species were monoterpenes and sesquiterpenes and as the major percentile was observed verbenone $(31.91 \%)$ in $C$. grandiflora and $\beta$-caryophyllene $(58.11 \%)$ in $C$. hilariana. In relation to $\beta$-caryophyllene as a major constituent of apolar fraction of species from section Phloianthera, these findings are consistent with those reported by Guimarães et al. (2013) for the major constituent of essential oil from leaves of Clusia lanceolata (43.20 - 56.40 \%) and by Fernandes et al. (2016) for essential oil of flowers of Clusia hilariana (37.1 - 49.0\%), who found $\beta$-caryophyllene also as major constituent.

The constituents of the apolar fraction of fruit latex of Clusia species have been investigated for the first time and showed in all species, independent of the taxonomic section, the presence of fatty acid derivatives, benzenoids and isoprenoids. Our study shows qualitative and quantitative differences in the chemical compositions for the studied Clusia species, even between species belonging to the same taxonomic group. As an explanation, one can exclude differences in the habitat as all plants, from which the fruits were collected, are cultivated in the same small area of Fazenda Sta. Elisa in Campinas, São Paulo state. Thus, a genetic basis of the chemical differences must be assumed. Only in few cases, the chemical data show correlation with phylogenetic relationship of the studied species as supported by morphological and DNA sequence data (Gustafsson et al. 2007). There are no data yet about differences in the latex chemistry within the same species and the possibility of an infraspecific variation cannot be excluded. It seems plausible that the latex a least partly serves to protect the developing seeds from herbivores, until the fruits (still carnose) open to expose the seeds to birds for dispersal. The very dense canals in the pericarp support this idea. However, the specific role of the observed latex constituents in such a supposed protection is unknown, and thus the efficiency of the different components to deter possible attacks. Nevertheless, during many visits to the plants cultivated in Campinas, we never observed immature fruits damaged by herbivores; apparently, the chemical defense is efficient.

\section{ACKNOWLEDGMENTS}

The authors are indebted to Coordenação de Aperfeiçoamento de Pessoal de Nível Superior (CAPES) for scholarship; Fundação de Amparo à Pesquisa do Estado de São Paulo (FAPESP); Conselho Nacional de Desenvolvimento Científico e Tecnológico (CNPq) for financial support and Instituto Agronômico de Campinas (IAC) for the permission to collect fruits from plants cultivated on Fazenda Sta. Elisa.

\section{REFERENCES}

ADAMS RP. 2007. Identification of Essential Oil Components by Gas Chromatography/Quadrupole Mass Espectroscopy, $4^{\text {th }}$ ed., Carol Stream: Allured Publishing Corporation, 804 p.

AGRAWAL AA AND KONNO K. 2009. Latex: a model for understanding mechanisms, ecology, and evolution of plant defense against herbivory. Annu Rev Ecol Syst 40: 311-331.

ANHOLETI MC, PAIVA SR, FIGUEIREDO MR AND KAPLAN MAC. 2015. Chemosystematic aspects of polyisoprenylated benzophenones from the genus Clusia. An Acad Bras Cienc 87: 289-301.

BARBOSA WLR AND PINTO LN. 2003. Documentação e valorização da fitoterapia tradicional Kayapó nas aldeias A’Ukre e Pykanu - Sudeste do Pará. Rev Bra Farmacogn 13: 47-49.

FARRELL BD, DUSSOURD DE AND MITTER C. 1991. Escalation of plant defense: do latex and resin canals spur plant diversification? Amer Naturalist 138: 881-900.

FERNANDES CP, CRUZ RAS, AMARAL RR, CARVALHO JCT, SANTOS MG, TIETBOHL LAC AND ROCHA L. 2016. Essential oils from male and female flowers of Clusia hilariana. Chem Nat Compd 52: 1110-1112.

GUIMARÃES ALA, BIZARRI CHB, BARBOSA LS, NAKAMURA MJ, RAMOS MFS AND VIEIRA ACM. 2013. Characterisation of the effects of leaf galls of Clusiamyia nitida (Cecidomyiidae) on Clusia lanceolata Cambess. (Clusiaceae): Anatomical aspects and chemical analysis of essential oil. Flora 208: 165-173. 
GUSTAFSSON MHG, BITTRICH V AND WINTER K. 2007. Diversity, phylogeny and classification of Clusia. In: Lüttge U (Ed), Clusia: a woody Neotropical genus of remarkable plasticity and diversity. Ecological Studies, Heidelberg: Springer 194: 95-116.

HUA J, LIU YC, JING SX, LUO SH AND LI SH. 2015. Macrocyclic diterpenoids from the latex of Euphorbia helioscopia. Nat Prod Commun 10: 2037-2039.

HUA J, LIU Y, XIAO CJ, JING SX, LUO SH AND LI SH. 2017. Chemical profile and defensive function of the latex of Euphorbia peplus. Phytochemistry 136: 56-64.

KNUDSEN JT, TOLLSTEN LAND BERGSTRÖM LG. 1993. Floral scents - a checklist of volatile compounds isolated by head-space techniques. Phytochemistry 33: 253-280.

KONNO K. 2011. Plant latex and other exudates as plant defense systems: roles of various defense chemicals and proteins contained therein. Phytochemistry 72: 1510-1530.

LEWINSOHN TM. 1991. The geographical distribution of plant latex. Chemoecology 2: 64-68.

LOKVAM J, BRADDOCK JF, REICHARDT PB AND CLAUSEN TP. 2000. Two polyisoprenylated benzophenones from the trunk latex of Clusia grandiflora (Clusiaceae). Phytochemistry 55: 29-34.

NOGUEIRA PC, BITTRICH V, SHEPHERD GJ, LOPES AV AND MARSAIOLI AJ. 2001. The ecological taxonomic importance of flower volatiles of Clusia species (Guttiferae). Phytochemistry 56: 443-452.

PORTO ALM, MACHADO SMF, OLIVEIRA CMA, BITTRICH V, AMARAL MCE AND MARSAIOLI AJ. 2000. Polyisoprenylated benzophenones from Clusia floral resins. Phytochemistry 55: 755-768.

SANZ-BISET J, CRUZ JC, RIVERA MAE AND CANIGUERAL S. 2009. A first survey on the medicinal plants of the Chazuta valley (peruvian Amazon). J Ethnopharmacol 122: 333-362.

VAN DEN DOOL AND KRATZ PD. 1963. A generalization of the retention index system including linear temperature programmed gas liquid partition chromatography. J Chromatogr A 11: 463-471.

WU SB, LONG C AND KENNELLY EJ. 2014. Structural diversity and bioactivities of natural benzophenones. Nat Prod Rep 31: 1158-1174. 